Przemysław Sieradzan*

\section{Bilans 70-lecia chińskich przemian}

DOI: http://dx.doi.org/10.12775/LC.2021.021

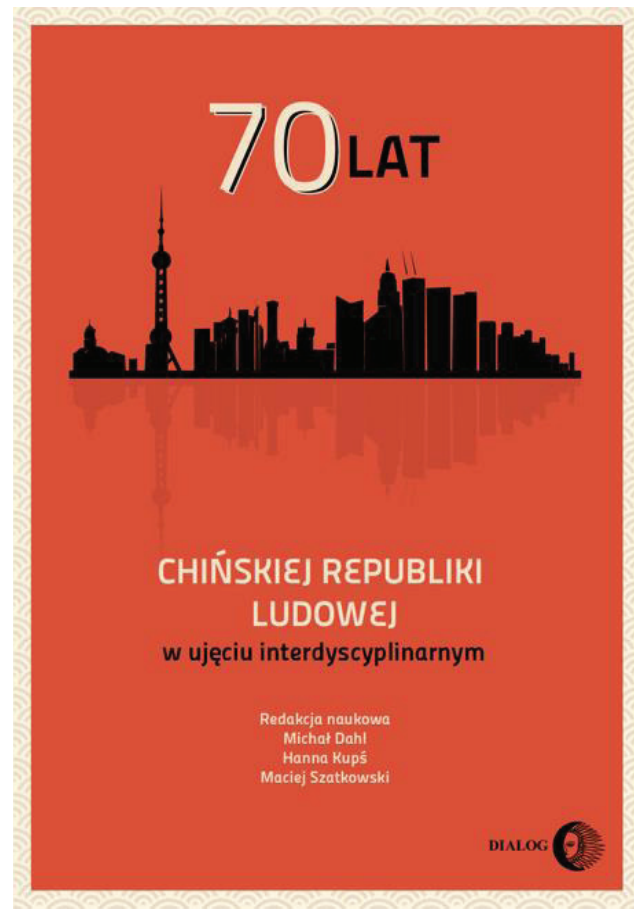

1

października 2019 roku minęło dokładnie 70 lat od słynnej proklamacji Mao Zedonga wygłoszonej na pekińskim Placu Tiananmen. Wydarzenie to uznaje się za

* Adiunkt w Zakładzie Kultury i Języków Azji Wschodniej Uniwersytetu Gdańskiego. Jego zainteresowania badawcze koncentrują się wokół społeczno-politycznej przestrzeni postradzieckiej, histori Rosji i Dalekiego Wschodu, stosunków międzynarodowych, heterodoksyjnych ruchów religijnych (politeizm, szamanizm, teozofia) oraz niekonwencjonalnej myśli politycznej.

E-mail: przemyslaw.sieradzan@ug.edu.pl | ORCID: 0000-0002-9255-7417. symboliczny początek Chińskiej Republiki Ludowej. Co prawda opór wojsk nacjonalistycznego Guomindangu jeszcze gdzieniegdzie się wówczas tlił, ale wojna domowa w kontynentalnej części państwa zmierzała już ku ostatecznemu i nieodwracalnemu rozstrzygnięciu. Skazywana wcześniej na nieuchronną porażkę Komunistyczna Partia Chin za sprawą niezwykle skutecznie i konsekwentnie realizowanej strategii wojny partyzanckiej zdobyła pełnię władzy, otwierając nowy rozdział w dziejach Państwa Środka. Siedemdziesięciolecie Chińskiej Republiki Ludowej to okres niezwykle kontrowersyjny, turbulentny, heterogeniczny i wewnętrznie złożony, naznaczony zarówno wydarzeniami dramatycznymi (jak choćby kampania Wielkiego Skoku Naprzód czy rewolucja kulturalna), jak i zdumiewającymi sukcesami (likwidacja analfabetyzmu i bezprecedensowy rozwój gospodarczy państwa po przełomie 1978 roku).

Monografia zbiorowa 70 lat Chińskiej Republiki Ludowej w ujęciu interdyscyplinarnym pod redakcją Hanny Kupś, Macieja Szatkowskiego i Michała Dahla jest pozycją niezwykłą. Nazwanie próby ujęcia tak skomplikowanej materii w ramach jednego tomu ambitnym zadaniem wydaje się równie adekwatne, co określenie Wielkiego Muru mianem interesującej budowli. Wyzwanie to jest po prostu niebotycznie trudne. Owa trudność wynika choćby z niewyobrażalnej wprost wieloaspektowości problemów badawczych, ogromnej rozległości zakresu podejmowanych zagadnień oraz niezwykłej złożoności opisywanego okresu historycznego. Niemniej jednak uważam, że autorzy i redaktorzy znakomicie sprostali podjętemu przez siebie zadaniu. Monografia ta z konieczności (ograniczona objętość kontrastująca $\mathrm{z}$ ogromem podjętego problemu) ma charakter propedeutyczny - jest dla Czytelnika przede wszystkim zachętą do dalszych poszukiwań i pogłębiania wiedzy 
o najnowszych dziejach Państwa Środka. $\mathrm{W}$ moim przekonaniu nie jest to jednak wada, lecz zaleta omawianej pracy.

Żyjemy w czasach dynamicznego wzrostu znaczenia Chin, któremu towarzyszy jednak szerzenie się mitów, stereotypów i uprzedzeń. Władze w Pekinie, ale i samo chińskie społeczeństwo, są współcześnie przedmiotem demonizacji i stereotypizacji, które nieuchronnie rodzą ignorancję i dzielą ludzi. Wartości, kultura i model cywilizacyjny rodzącego się supermocarstwa nadal spotykają się z niezrozumieniem nie tylko w Polsce, ale i w całym świecie zachodnim. Szkodliwe mity i uprzedzenia, generujące groźne animozje, jak zawsze mają swoje źródło w niewiedzy.

$\mathrm{Na}$ polskim rynku wydawniczym brakowało właśnie syntetycznego, wielowymiarowego ujęcia rozmaitych aspektów składających się na fascynujący obraz ostatnich siedmiu dekad w dziejach państwa chińskiego. Praca zborowa, która ukazała się nakładem warszawskiego wydawnictwa Dialog, $\mathrm{w}$ znacznym stopniu wypełnia tę lukę.

Wśród autorów monografii znaleźli się najlepsi polscy specjaliści zajmujący się różnymi aspektami chińskiej państwowości - przede wszystkim uczeni reprezentujący różne dyscypliny naukowe i różne pokolenia, ale także dyplomaci. Znaczną część autorów stanowią zawodowi sinolodzy. Zespół autorski wzbogaca jednak obecność badaczy reprezentujących także i inne dziedziny, takie jak politologia, ekonomia czy kulturoznawstwo. Dzięki ich współpracy udało się uzyskać znakomity efekt synergetyczny.

Monografia z konieczności skupia się na wybranych kategoriach tematycznych. Podzielona została na trzy obszerne części, zatytułowane Polityka, Ekonomia i Kultura. Struktura pracy wydaje się przemyślana, logiczna i uzasadniona, choć oczywiście granice między zakresami problematycznymi powyższych trzech kategorii są - bo i muszą być, jak to w humanistyce - nieostre.

Część politologiczną monografii otwiera studium profesora Bogdana Góralczyka, bez wątpienia należącego do wąskiego grona najwybitniejszych polskich znawców Azji Wschodniej, poświęcone systemowi politycznemu Chińskiej Republiki Ludowej po 1978 roku, przedstawionemu w szerokiej perspektywie historycznej, wraz z całą paletą uwarunkowań natury ideologicznej i cywilizacyjnej. Bardzo interesujące i przekonujące wydały mi się uwagi dotyczące wewnętrznych sprzeczności w kolektywnym kierownictwie Komunistycznej Partii Chin oraz teza o wyraźnym odchodzeniu przez Xi Jinpinga od dziedzictwa Deng Xiaopinga, wyrażającym się między innymi w postępującej centralizacji i personalizacji władzy. Odrodzenie ideologii konfucjańskiej dokonujące się w marksistowsko-leninowskich Chinach w swoim erudycyjnym artykule opisał Marek Tylkowski. W tym przypadku szczególnie zainteresowały mnie uwagi na temat singapurskich inspiracji opisywanego fenomenu oraz rozważania na temat powiązań renesansu myśli mędrca z prowincji Shandong z chińską drogą do socjalizmu („konfucjanizacja marksizmu”). Antonina Łuszczykiewicz poddała analizie wpływ Pięciu Zasad Pokojowego Współistnienia na chińską politykę zagraniczną oraz dyskurs kulturowy, skupiając się przede wszystkim na genezie koncepcji i jej wpływie na relacje Pekinu z New Delhi. Warto odnotować przede wszystkim nowatorskie podejście do zagadnienia (przekonujące wykazanie aktualności formuly wbrew błędnym tezom $\mathrm{z}$ innych opracowań, według których ma ona charakter historyczny, ograniczony do czasów konferencji z Bandungu) oraz niezwykle bogaty materiał źródłowy. Marek Świstak w swoim tekście podjął z kolei problematykę z pogranicza ekonomii i polityki, koncentrując się na wewnętrznych 
sprzecznościach gospodarki i władzy w Chińskiej Republice Ludowej, w szczególności na napięciach generowanych przez dialektykę mechanizmów rynkowych i socjalistycznych fundamentów ustrojowych.

Rozmaite problemy związane z życiem gospodarczym Chińskiej Republiki Ludowej podejmuje część zatytułowana Ekonomia. Magdalena Rybicka w swoim studium dokonała analizy ewolucji chińskiego rynku w XXI wieku, wskazując na jego rosnącą innowacyjność. Wielką zaletą tekstu jest syntetyczne ujęcie bardzo złożonego problemu oraz klarowny, logiczny wywód. Tekst Kamila Waligóry poświęcony jest zaś problematyce handlu zagranicznego. Autor umiejętnie łączy prezentację zgromadzonych przez siebie danych statystycznych i makroekonomicznych $\mathrm{z}$ fachowym przedstawieniem szerszego kontekstu politycznego i międzynarodowego. Kamil Kotliński skoncentrował się na zagadnieniach regionalnych różnic dochodowych. Na podstawie obszernych zasobów danych i pieczołowicie przeprowadzonych badań wykazal, że regionalne nierówności dochodowe w Chinach stopniowo maleją. Joanna Wardęga poświęciła swój artykuł turystyce i jej znaczeniu dla pozycji międzynarodowej Chin. Przedstawiła obszerne dane i wpisała sferę turystyki w perspektywę soft power. Nie ustrzegła się jednak pewnych zwrotów i sformułowań o charakterze publicystycznym. Michał Zaremba przeanalizował problemy chińskiej pomocy rozwojowej. Artykuł przedstawia zarówno ewolucję historyczną zagadnienia, jak i bieżące trendy w opisywanej dziedzinie. Autor, posługując się licznymi dokumentami i opracowania$\mathrm{mi}$, analizuje pomoc rozwojową jako istotne narzędzie polityki międzynarodowej państwa. Autorami ostatniego tekstu należącego do części ekonomicznej, poświęconego przepływom między Chinami, USA i Unią Europejską w perspektywie globalizacji są
Adam Chlebisz i Mateusz Mierzejewski. Autorzy nie tylko zgromadzili obszerne dane z zakresu chińskiej makroekonomii, ale też zastosowali do ich analizy złożone modele ekonometryczne.

Część poświęconą kulturze otwiera studium Natalii Lubińskiej i Moniki Paliszewskiej-Mojsiuk na temat reform edukacji w Chinach, koncentrujące się przede wszystkim na aspekcie umasowienia niegdyś elitarystycznego i zamkniętego modelu edukacji po zwycięstwie rewolucji 1949 roku. Maciej Gaca przedstawił badania nad procesem sinizacji mniejszościowych grup etnicznych w Chińskiej Republice Ludowej i na Tajwanie, zwracając uwagę zarówno na aspekt etnologiczny, jak też ideologiczny i polityczny zagadnienia. Studium Marka Piszczka dotyczy rozwoju kaligrafii w Chińskiej Republice Ludowej i uwzględnia przede wszystkim problemy edukacji i szkolnictwa. Na ogromny podziw zasługuje bogactwo danych i materiałów zdobytych i opracowanych przez autora. Hanna Kupś zbadała zagadnienia związane $\mathrm{z}$ archeologią muzyczną w Chinach. Tekst jest niezwykle bogaty faktograficznie i oparty na ogromnej bazie źródłowej. Monografię wieńczy bogato ilustrowany tekst Joanny Kucharzewskiej poświęcony ewolucji architektonicznej Pekinu. Autorka, będąc niewątpliwą znawczynią podejmowanej problematyki, opisuje turbulentne urbanistyczne dzieje północnej chińskiej stolicy od tradycyjnego chińskiego miasta zaprojektowanego w oparciu o filozoficzną zasadę komplementarności przeciwieństw aż do nowoczesnej metropolii, poświęcając szczególną uwagę zagadnieniu ochrony tradycyjnej zabudowy.

Monografię zbiorową 70 lat Chińskiej Republiki Ludowej $w$ ujęciu interdyscyplinarnym bez najmniejszego zastanowienia mogę polecić każdemu czytelnikowi zainteresowanemu problemami politycznymi, gospodarczymi i kulturowymi Chin 
współczesnych. Jest ona znakomitym wprowadzeniem $\mathrm{w}$ tematykę przemian, które dokonały się w Państwie Środka w ostatnim siedemdziesięcioleciu. Oczywiście, z racji obszernego zakresu tematycznego i ograniczonej objętości nie jest to opracowanie kompletne i wyczerpujące - nie mogłoby takim być. Jestem jednak przekonany, że zaprezentowane $\mathrm{w}$ nim interdyscyplinarne, syntetyczne spojrzenie na opisywane zjawiska i procesy wniesie znaczący pozytywny wkład w dyskurs naukowy poświęcony Chinom współczesnym.

\section{Bibliografia}

Kupś, Hanna [\&] Maciej Szatkowski [\&] Michał Dahl (red.) 2021. 70 lat Chińskiej Republiki Ludowej w ujęciu interdyscyplinarnym. Warszawa: Wydawnictwo Akademickie Dialog. 